\title{
MOLECULAR ANALYSIS OF THE BACTERIAL DIVERSITY IN A SPECIALIZED CONSORTIUM FOR DIESEL OIL DEGRADATION $^{(1)}$
}

\author{
Douglas Antonio Alvaredo Paixão ${ }^{(2)}$, Mauricio Rocha Dimitrov ${ }^{(3)}$, Rodrigo \\ Matheus Pereira $^{(4)}$, Fábio Raphael Accorsini ${ }^{(5)}$, Maria Benincasa Vidotti ${ }^{(5)}$ \& \\ Eliana Gertrudes de Macedo Lemos ${ }^{(6)}$
}

\begin{abstract}
SUMMARY
Diesel oil is a compound derived from petroleum, consisting primarily of hydrocarbons. Poor conditions in transportation and storage of this product can contribute significantly to accidental spills causing serious ecological problems in soil and water and affecting the diversity of the microbial environment. The cloning and sequencing of the $16 \mathrm{~S} r R N A$ gene is one of the molecular techniques that allows estimation and comparison of the microbial diversity in different environmental samples. The aim of this work was to estimate the diversity of microorganisms from the Bacteria domain in a consortium specialized in diesel oil degradation through partial sequencing of the $16 S$ rRNA gene. After the extraction of DNA metagenomics, the material was amplified by PCR reaction using specific oligonucleotide primers for the $16 S$ rRNA gene. The PCR products were cloned into a pGEM-T-Easy vector (Promega), and Escherichia coli was used as the host cell for recombinant DNAs. The partial clone sequencing was obtained using universal oligonucleotide primers from the vector. The genetic library obtained generated 431 clones. All the sequenced clones presented similarity to phylum Proteobacteria, with Gammaproteobacteria the most present group (49.8\% of the clones), followed by Alphaproteobacteira (44.8 \%) and Betaproteobacteria (5.4 \%). The Pseudomonas genus was the most abundant in the metagenomic library, followed by the Parvibaculum and the Sphingobium genus, respectively. After partial sequencing of the $16 S r R N A$, the diversity of the bacterial consortium was estimated using DOTUR software. When comparing these sequences to the
\end{abstract}

\footnotetext{
(1) Received for publication in Juny 2009 and approved in March 2010.

(2) MSc. in Microbiology da FCAV (UNESP - São Paulo State University). Rod. Paulo Donato Castellane s/n, CEP 14884-900 Jaboticabal - São Paulo - Brasil. Email: douglas_unespfcav@yahoo.com.br

${ }^{(3)}$ MSc. in Biotechnology University of São Paulo (USP). E-mail: mau_dimitrov@yahoo.com.br

(4) Embrapa Soybean. Rod. Carlos João Strass - Distrito de Warta CEP 86001-970 - Londrina- Paraná- Brasil. E-mail: poetbr@gmail.com

(5) Department of Biology applied to the agricultural and animal husbandry development of the FCAV (UNESP - São Paulo State University). E-mail: vidotti@netsite.com.br

${ }^{(6)}$ Full Professor of biochemistry FCAV (UNESP - São Paulo State University). E-mails: egerle@fcav.unesp.br
} 
database from the National Center for Biotechnology Information (NCBI), a strong correlation was found between the data generated by the software used and the data deposited in NCBI.

Index terms: PCR, cloning, 16S rRNA, metagenomics, soil, biosurfactants.

\author{
RESUMO: ANÁLISE MOLECULAR DA DIVERSIDADE BACTERIANA DE \\ UM CONSÓRCIO DEGRADADOR DE ÓLEO DIESEL
}

\begin{abstract}
O óleo diesel é um composto derivado do petróleo, constituido basicamente por hidrocarbonetos. Condições precárias no processo de transporte e armazenagem desse produto contribuem significativamente para derrames acidentais, ocasionando sérios problemas ecológicos no solo e água, alterando assim toda a diversidade microbiológica do ambiente. A estratégia de clonagem e sequenciamento do gene $16 \mathrm{~S}$ rRNA é uma das técnicas moleculares que permitem estimar e comparar a diversidade microbiana de diferentes amostras ambientais, sejam elas impactadas ou não. O objetivo deste trabalho foi estimar a diversidade de microrganismos pertencentes ao domínio Bacteria em um consórcio degradador de óleo diesel por meio de sequenciamento parcial do gene $16 \mathrm{~S}$ rRNA. Após extração do DNA metagenômico, o material foi amplificado por reação de PCR com oligonucleotídeos iniciadores específicos para o gene $16 \mathrm{~S}$ rRNA. Os produtos da reação de PCR foram clonados em vetor $p$ GEM T Easy (Promega) e transformados em células competentes de Escherichia coli. O sequenciamento parcial dos clones foi feito com oligonucleotídeos universais do vetor. A biblioteca obtida gerou 431 clones. Todos os clones mostraram similaridade com o filo Proteobacteria, onde as Gammaproteobacteria compreenderam o grupo de maior representatividade, com $49,8 \%$ dos clones, seguida das Alphaproteobacteira, com 44,8 \%, e das Betaproteobacteria, com 5,4\%. O gênero Pseudomonas destacou-se como representante com maior frequência de clones na biblioteca, seguido pelos gêneros Parvibaculum e Sphingobium. Após o sequenciamento parcial do gene 16S rRNA, a diversidade bacteriana do consórcio foi estimada utilizando-se o software DOTUR. Essas sequências, quando comparadas com as do banco do National Center for Biotechnology Information (NCBI), mostraram grande correlação entre os dados gerados pelo software utilizado e aqueles depositados no NCBI.
\end{abstract}

Termos de indexação: PCR, clonagem, $16 \mathrm{~S}$ rRNA, metagenoma, solo, biosurfactantes.

\section{INTRODUCTION}

Brazil is one of the largest producers of petroleum oil in the world. According to the Brazilian National Oil Production agency (ANP), in 2008 Brazil produced approximately 96.371 .606 million $\mathrm{m}^{3}$ of this oil. As a direct consequence of these high production, concerns regarding the risk of accidents such as oil spillage and environmental contamination became prominent, especially concerns regarding possible contamination of soil and subterranean water sources. According to research done by a Brazilian state agency responsible for water distribution in 2007 (Cetesb), fuel sale stations are those with the highest potential to generate soil and water contamination, being responsible for $77 \%$ of the notifications concerning contamination of water sources (Cetesb, 2007).

Diesel oil is composed of a mixture of alkenes and aromatic compounds which are frequently found as contaminants in soil following accidental oil spillage (Gallego et al., 2001). To restore the original quality of the contaminated soil area, many techniques are used in the process of removing the hydrocarbons. Some of these techniques use physical and chemical processes, such as the incineration and washing of the affected soil. The use of microorganisms capable of degrading toxic compounds by the process denominated bioremediation can contribute to the recovery of contaminated soil (Bento et al., 2005b). This technique uses endogenous microorganisms previously isolated from contaminated areas to promote the removal of pollutants from natural environments and the conversion of these pollutants into inert substances (Bamforth \& Singleton, 2005). It is a method that can be very useful and practical for the removal of certain pollutants, although successful results depend on the combining of the microorganisms with adequate environmental factors at the site, such as nutrient, oxygen and $\mathrm{pH}$ levels, as well as local temperatures.

A varied group of microorganisms stand out regarding their capacity to process and decompose 
hydrocarbons derived from oil. These include bacteria species from genera Pseudomonas, Aeromonas, Beijerinckia, Flavobacterium, Nocardia, Corynebacterium, Sphingomonas, Mycobacterium, Stenotrophomonas, Paracoccus, Burkholderia, Microbacterium, Gordonia and many fungi from genera Cunnighamella, Phanerochaete, Fusarium, Candida, Penicillium, Pleorotus, Trametes, Aspergillus, Bjerkandera and Chrysosporium. However, the use of microbial consortium has been found as being more effective in the degradation of these compounds (Jacques et al., 2007).

Many genetic tools are used to typify microbial communities from many environments without the need of cultivation (Kowalchuk et al., 2004). Of these, the sequencing of gene $16 \mathrm{~S} r R N A$ is of much use. This specific gene is formed by a primary structure composed of areas which alternate between constant and variable regions, and allows a broad investigation for the determination of phylogenetic relationships (Ludwig $\&$ Schleifer, 1994). The precision of the phylogenetic inference obtained depends not only on the number of bases that are compared, but also on the areas that are compared (Hurst et al., 2002). Thus, the partial sequencing of the $16 S \mathrm{rRNA}$ gene is an important tool for analysis of the diversity of microorganisms existing in bacterial communities from environmental samples. The use of this technique has provided very good results in estimating and comparing bacterial communities from different samples and different environments (Kuske et al., 1997; Pereira et al., 2006; Silveira et al., 2006; Val-Moraes et al., 2009).

Obtaining better knowledge and understanding the microorganism diversity pertaining to bacterial communities from affected environments is important and imperative to attain economical and strategic benefits such as those that would be obtained with the discovery of microorganisms that present potential for being used in biotechnological processes for bioremediation of contaminated areas. The present work used partial sequencing of the $16 \mathrm{~S} r R N A$ gene to estimate the diversity of microorganisms of the Bacteria domain in a consortium specialized in diesel oil degradation.

\section{MATERIALS AND METHODS}

\section{Obtaining the microbe consortium}

The microbe consortium assessed was developed and provided by researcher Maria Benincasa Vidotti, $\mathrm{PhD}$, from the Department of Biology applied to the agricultural and animal husbandry development of the FCAV/UNESP, who kindly allowed its use in the present study.

The soil used for obtaining the consortium was collected from a contaminated site located in Ribeirão Preto County, São Paulo State (Brazil), at 21 $06^{\circ} \mathrm{S}$, $47^{\circ} 49^{\prime} \mathrm{O}$, which held, in the past, a factory that manufactured automotive lubricants. The subsamples of the soil were collected randomly, at 0-20 cm of depth, following a zigzagging pattern. After the collected samples were homogenized, and from the total amount of soil collected (approximately $500 \mathrm{~g}$ ), $1 \mathrm{~g}$ was added to $50 \mathrm{~mL}$ of sterile mineral Bushnell-Haas Broth medium (B.H.B) composed of $\left(\mathrm{g} \mathrm{L}^{-1}\right): \mathrm{MgSO}_{4}, 0.2$; $\mathrm{KH}_{2} \mathrm{PO}_{4}, 1.0 ; \mathrm{CaCl}_{2}, 0.02 ;\left(\mathrm{NH}_{4}\right)_{2} \mathrm{HPO}_{4}, 1 ; \mathrm{KNO}_{3}, 1$; $\mathrm{FeCl}_{3}, 0.05$ (Bushenell \& Haas, 1941), and maintained for $12 \mathrm{~h}$ at $30^{\circ} \mathrm{C}$ under constant agitation at $150 \mathrm{rpm}$. Afterwards, the suspensions were left to rest for one hour for decantation of the solid phase. For enrichment, a $500 \mu \mathrm{L}$ aliquot of the supernatant was inoculated into $50 \mathrm{~mL}$ of the sterile B.H.B medium containing $0.1 \%(\mathrm{v} / \mathrm{v})$ of diesel oil, sterilized by filtration through $0.22 \mu \mathrm{m}$ membranes (Millipore), which was used as the only source of $\mathrm{C}$. The consortium began to be harvested after seven days of the culture's development.

Extraction of metagenomic DNA from the consortium and amplification of the $16 \mathrm{~S} r \mathrm{RNA}$ gene

The extraction of the metagenomic DNA from the consortium was done using a FastDNA ${ }^{\circledR}$ SPIN Kit for Soil (BIO 101-QUANTUM BIOTECHNOLOGIES), following the manufacturers instructions. Metagenomic DNA was used for the amplification of the $16 S$ rRNA gene by PCR. In the reaction, the fD1 (position 8-27) and rD1 (position 1524-1540) initiating oligonucleotides from the $16 S \mathrm{rRNA}$ gene in Escherichia coli, strain K12, were used as indicated by Weisburg et al. (1991). Conditions added were modified as follows: PCR Buffer 1X [20 mmol L-1 Tris$\mathrm{HCl}(\mathrm{pH} 8.4), 50 \mathrm{mmol} \mathrm{L}^{-1} \mathrm{KCl}$, $200 \mathrm{mmol} \mathrm{L}^{-1}$ of each dNTP, $2 \mathrm{mmol} \mathrm{L}^{-1} \mathrm{MgCl}_{2}, 1.25 \mathrm{U}$ Taq DNA Polimerase, $5 \mathrm{pmol}$ of each initiator, $35 \mathrm{ng}$ of metagenomic DNA and pure water completing $50 \mathrm{~mL}$ (final volume) of the reaction. For the PCR reaction an MJ Research Inc. thermocycler, model PTC - 200 was used with the following program: $94{ }^{\circ} \mathrm{C}$ for $2 \mathrm{~min}$, 35 cycles at $94^{\circ} \mathrm{C}$ for $30 \mathrm{sec}, 55^{\circ} \mathrm{C}$ for $50 \mathrm{sec}, 72^{\circ} \mathrm{C}$ for $2 \mathrm{~min}$ and $72^{\circ} \mathrm{C}$ for $5 \mathrm{~min}$. The amplicons generated were confirmed by electrophoresis in $1 \%$ Agar gel containing $0.5 \mu \mathrm{g} \mathrm{mL}^{-1}$ ethidium bromide, buffer TBE (Tris $89 \mathrm{mmol} \mathrm{L}^{-1} ; 89 \mathrm{mmol} \mathrm{L}^{-1}$ boric acid and $2.5 \mathrm{mmol} \mathrm{L}^{-1}$ EDTA, $\mathrm{pH}$ 8.3) and visualized by a photo documenter Gel Doc 1000 (Bio Rad, USA) with UV light.

\section{Cloning and partial sequencing of the $16 S$ rRNA gene}

The amplified product of the $16 \mathrm{~S} r R N A$ gene was cloned in a pGEM-T Easy vector (Promega, Madison, WI, USA) following the manufacturer's instructions. Competent DH5 $\alpha$ Escherichia coli cells were used for the transformation (Hanahan, 1983). The transforming clones were selected in Petri dishes containing a Luria Bertani medium (LB) supplemented with ampicilin $\left(100 \mu \mathrm{g} \mathrm{mL}^{-1}\right)$. 
The selected clones were harvested in $1 \mathrm{~mL}$ of a Circle Grow (CG) medium containing ampicilin $\left(100 \mu \mathrm{g} \mathrm{mL}^{-1}\right)$ and were then cultivated for $22 \mathrm{~h}$ at $37^{\circ} \mathrm{C}$ under constant agitation at $250 \mathrm{rpm}$. The plasmid DNA selected from the clones was extracted according to the method suggested by Sambrook \& Russell (2001) and purified using MultiScreen filters (Millipore). The plasmids containing the $16 \mathrm{~S}$ rDNA fragments were sequenced using $0.5 \mu \mathrm{L}$ of DYEnamic ET Terminator Cycle Sequencing Kit (GE Healthcare); $10 \mathrm{pmol}$ of the T7 sequence promoter initiating oligonucleotide (20 mer); $150 \mathrm{ng}$ of plasmid DNA in a final volume of $10 \mu \mathrm{L}$. The sequencing reaction was done using micro plates which held 96 wells. The conditions in the thermocycler were as following: $2 \mathrm{~min}$ at $95{ }^{\circ} \mathrm{C}, 40$ cycles of $95{ }^{\circ} \mathrm{C}$ for $30 \mathrm{sec}, 50{ }^{\circ} \mathrm{C}$ for $15 \mathrm{sec}$, and $60^{\circ} \mathrm{C}$ for $2 \mathrm{~min}$. The samples were submitted to precipitation using $75 \%$ isopropyl alcohol and then rinsed with $70 \%$ ethanol. The amplicons were sequenced using a model ABI 3700 sequencer (Applied Biosystems, Foster City, CA, USA).

\section{Sequence analysis}

After the sequencing process, the electropherograms produced were analyzed by a $\mathrm{Phred} / \mathrm{Phrap}$ program (Ewing et al.,1998a; Ewing \& Green, 1998b) used for the detection of the level of confidence for each sequenced base and the formation of the contigs respectively. With the aid of another program, ContGEN, only the sequences which presented more then 400 bases of Phred quality $\geq 20$ were selected. Initial regions containing sequences of vectors were extracted with the aid of the sequence analysis module of the OC Identifier tool (Cantão et al., 2007). All the sequences were inserted into the metagenomic data bank and metagenomic data in the Laboratory of Microorganism and Plant Biochemistry (Laboratório de Bioquímica de Microrganismos e Plantas) at UNESP-FCAVJ (http://lbmp.fcav.unesp.br/ metagenoma). First, the sequences were compared to those from the international gene bank (National Center for Biotechnology Information - NCBI) using the BLASTN tool (Altschul et al., 1997), to identify the different sequences based on the "Gene IDs". The distinct sequences were then compared to the bank of ribosomal data from the Ribosomal Database Project II (Cole et al., 2009), using the Classifier program (Wang et al., 2007). For the phylogenetic relationship analysis, the distinct sequences were aligned using the ClustalX 1.83 program (Thompson et al., 1997). The phylogenetic tree was then constructed using the Mega 4 program (Tamura et al., 2007) with the algorithm of the closest neighbor-joining organism (Saitou \& Nei, 1987) and the nucleotide substitution model Kimura 2-P (Kimura, 1980). The result of the alignment was also used for building a distance matrix with the DNAdist program (Falsensten, 1989), and this matrix was then used as a way of entry for data in the DOTUR program (Schloss \& Handelsman, 2005) for assessment of sample sufficiency regarding diversity.

\section{Numbers for access to the nucleotide sequences}

All the 16S rDNA sequences obtained in the present study were registered in the International Gene Bank (GenBank) and received as access numbers from FJ978048 to FJ978478.

\section{RESULTS AND DISCUSSION}

The metagenomic DNA isolated in the study was of satisfactory quality, was found to be free of contamination by protein and RNAs, and produced molecular sizes of close to $20 \mathrm{~Kb}$. The amplification of this material using the $\mathrm{fD} 1 / \mathrm{rD} 1$ initiators generated $1,500 \mathrm{pb}$ fragments, which were used for the construction of the $16 \mathrm{~S}$ rRNA gene metagenomic library. The library generated 480 clones, of which 431 presented enough quality for the analysis and identification of phylogenetic groups.

Following the proposal of the second edition of Bergey's trust Manual, which classifies the taxonomic levels in Domain, Phylum, Class, Order, Family, Genera and Species, the classification employed by the Classifier program grouped the library sequences in the following manner: 1 phylum, 3 classes, 5 orders, 8 families and 11 genus. All the $16 \mathrm{~S}$ rDNA sequences identified belong to the Proteobacteria phylum, with 419 (97.2 \%) of these distributed between three distinct Alpha, Beta and Gammaproteobacteria classes. The other 12 sequences (2.8\%) were not able to be classified at the taxonomic class level.

Of the three identified classes, Gammaproteobacteria was the one with the highest number of components (49.8\% of the clones), followed by Alphaproteobacteira with $44.8 \%$ and Betaproteobacteria with $5.4 \%$.

The comparison of the $43116 \mathrm{~S}$ rDNA sequences from the consortium library to the international gene bank (NCBI) showed that 55 sequences were distinct, representing $14 \%$ of all the sequenced clones. This distinction was identified based on comparison to the sequence codes known as "Gene IDs". Each distinct sequence obtained was defined as an operational taxonomic unit (OTU) (Figures 1 and 2).

The fifty five distinct sequences were compared to the ribosomal 16S rDNA sequence data bank of Database Project $I I$ with $95 \%$ confidence, and showed similarity to genus: Variovax, Flavimonas Stenotrophomonas, Cupriavidus, Sphingomonas, Bosea, Bordetela, Thermomonas, Achromobacter, Pseudomonas, Parvibaculum, and Sphingobium. These last three genus were, respectively, the taxons presenting the highest frequencies regarding the number of clones from the library (Figure 3). Partial sequencing of the $16 S$ rRNA gene is a reliable technique, and has been used frequently for the identification of microorganisms, these being from cultures (Toledo et al., 2009), or available from environmental samples (Nercessian et al., 2008). 


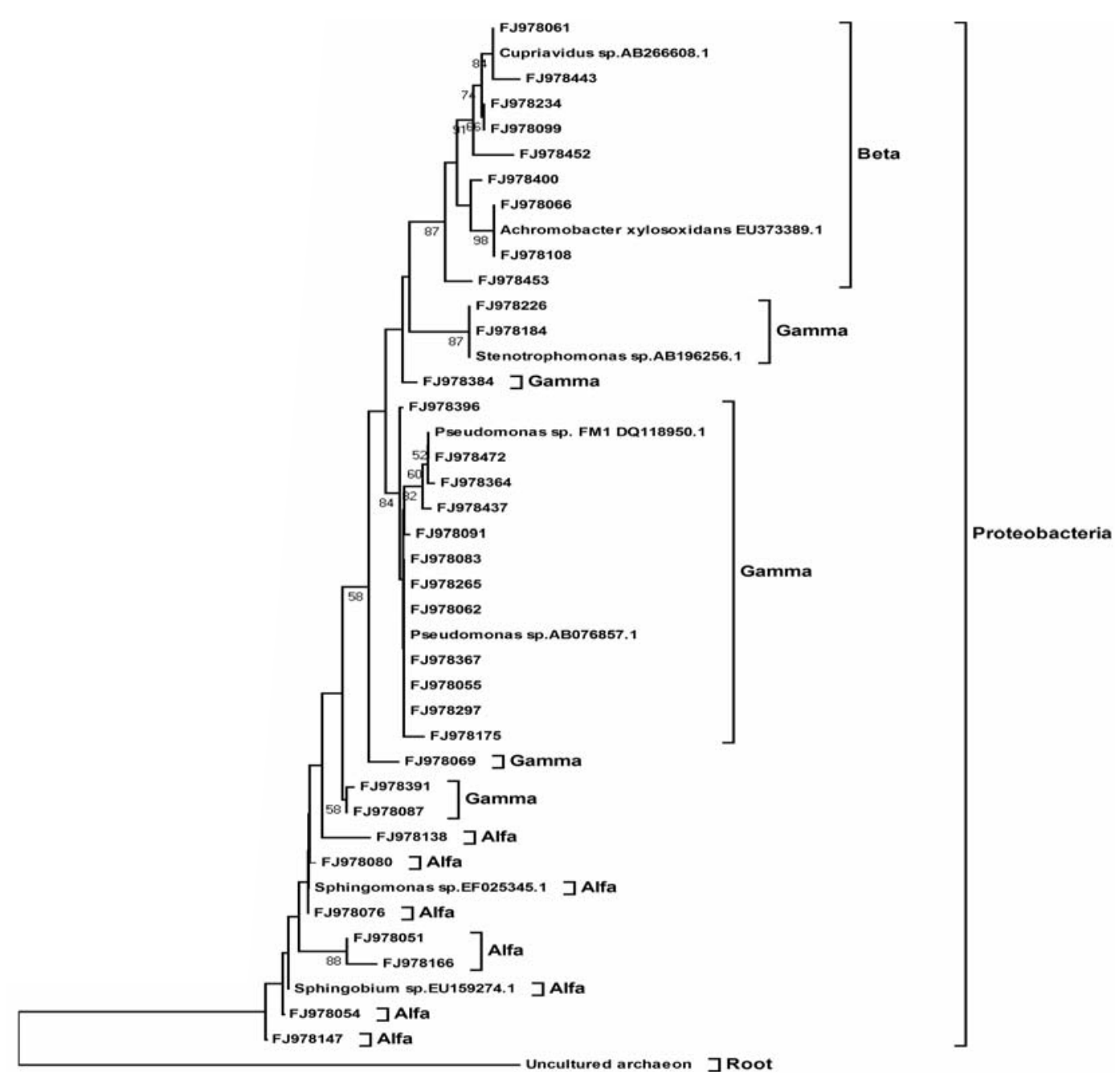

Figure 1. Phylogenetic tree based on the partial sequences of 16S rDNA from the consortium, generated by the MEGA program, version 4. The distance matrix was calculated using the "Neighbor-Joining" algorithm and the nucleotide substitution method "Kimura 2-P", with a "bootstrap" of 1000 repetitions.

All genus identified in this study had already been found to be involved in the degradation of hydrocarbons reported in published literature.

The Pseudomonas group was the genus that most consistently appeared in the library, pertaining to $32.2 \%$ of the total clones, followed by genus Parvibaculum with $29 \%$ and Sphingobium with $12 \%$.

The DOTUR software allowed the determination of the number of operational taxonomic units (OTUs). The results were also used for the construction of the rarefaction curve. The design of the rarefaction curve can be used to determine if the size of the samples taken was sufficient to reveal the total diversity of a community (Roesch et al., 2007). In the present study, two rarefaction curves were tested, represented by $97 \%$ and $90 \%$ of similarity, as criterion for grouping (figure 4). The analysis of the figure showed an initial ascendancy of both curves, which tended to attain a plateau when at approximately 60 taxonomic units in the curve that represented $97 \%$ of similarity.
On the other hand, the curve with grouping criterion that presented $90 \%$ of similarity attained its plateau when coming close to 20 taxonomic units. These results reveal that the number of $16 \mathrm{~S}$ rDNA clones sequenced was close to the total number of individuals which composed the bacterial community sampled. These results agree with those observed when comparing the clone sequences with the gene bank of the National Center for Biotechnology Information (NCBI), in which the number of identified OTUs was 55. The correlation of the obtained data compared to that from the international gene bank, added to the data generated by the DOTUR program, confirms that the estimates regarding the diversity of microorganisms in the consortium was attained.

The assessment of the bacterial diversity through the sequencing of $16 \mathrm{~S} r R N A$ shows that organisms from phylum Proteobacteria are a common presence in different types of soil (Kuske et al. 1997; Pereira, et al. 2006; Silveira et al, 2006; Val-Morais et al. 2009). Besides this find, studies of bacterial diversity 


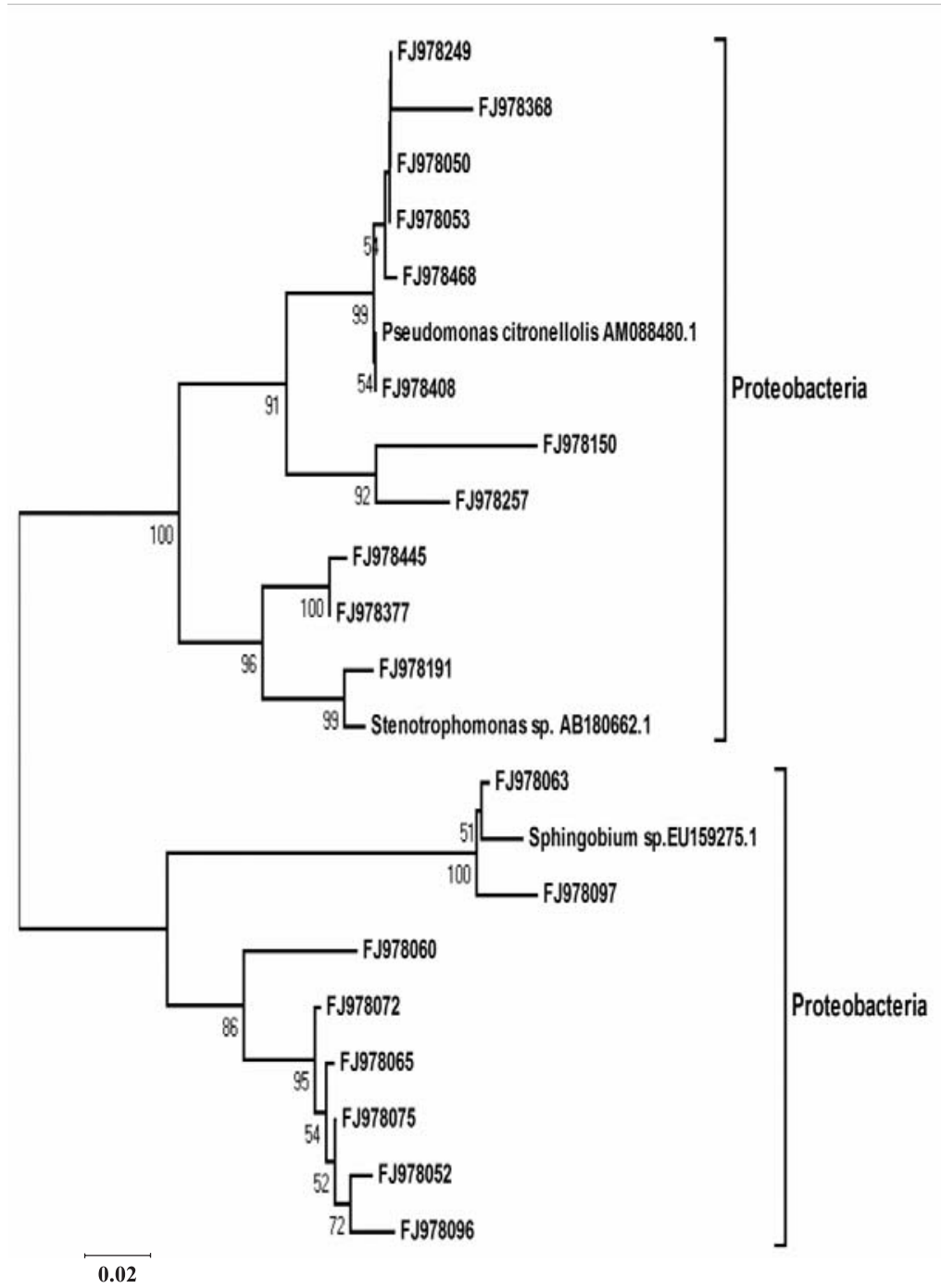

Figure 2. Phylogenetic tree based on the partial sequences of $16 \mathrm{~S} r D N A$ from the consortium, generated by the MEGA program, version 4. The distance matrix was calculated by the "Neighbor-Joining" algorithm and the nucleotide substitution method "Kimura 2-P", with a "bootstrap" of 1000 repetitions.

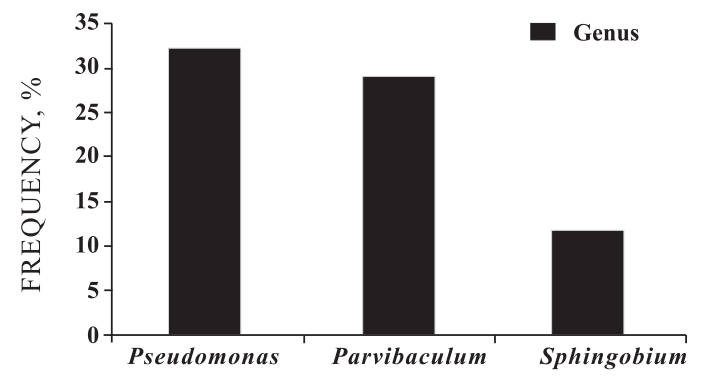

Figure 3. Frequency of clones from the most represented genus in the $16 \mathrm{~S} r D N A$ library from the consortium.

in soils sustaining intensive culture systems (Pereira et al. 2006; Val-Morais et al. 2009), as well as in areas of environmental preservation in which human interference does not occur, show that this phylum is present in the most predominant bacterial communities (Silveira et al. 2006). Similar results

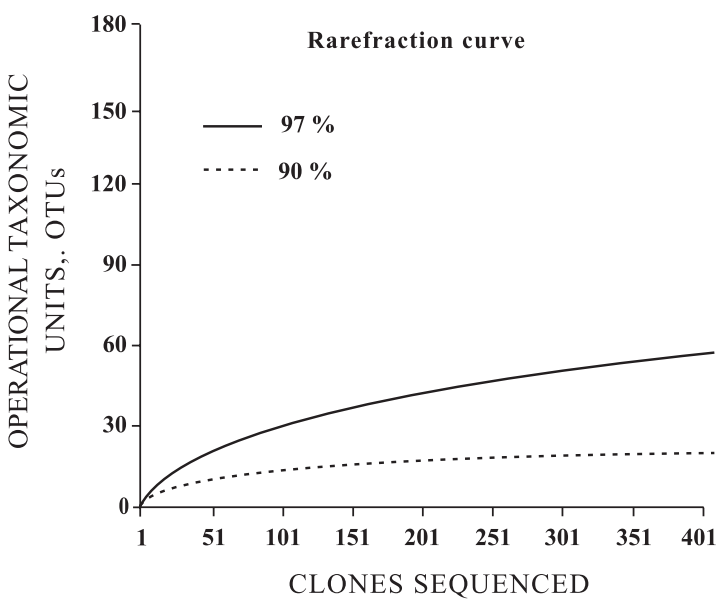

Figure 4. Rarefaction curves calculated by the DOTUR program using 97 and $90 \%$ of similarity for grouping of the $16 \mathrm{~S} r D N A$ sequences from the consortium clone library. 
can be observed when assessing soils that present a record of contamination by hydrocarbons (Wunsche et al. 1995; Ozaki et al 2006).

The Proteobacteria phylum is considered to be one of the largest and most diverse of the Bacteria domain, occurring in the most varied environments, with approximately 528 genus already described (Garrity et al., 2004). Furthermore, the components of this phylum are considered as being efficient in hydrocarbon degradation, including aromatic, aliphatic and other components (Atlas, 1981). The diversity of this phylum in many different types of environments is associated to the large morphologic and metabolic variety of the organisms that compose this group (Pereira et al 2006), such as chemolithotrophs, chemoorganotrophs and phototrophs which use diverse strategies for obtaining energy (Canhos et al. 1997). Some studies also have associated the presence of these groups of bacteria to certain nutritional conditions in the soil, since some bacteria from class Alphaproteobacteria develop with more ease in fertile soil (Mccaig et al. 1999). Microbiologic evaluations such as the present add to the knowledge regarding ecology and bacterial diversity attained in this field of study, since it allows the assessment and monitoring of bacterial groups in the most varied environments, especially regarding different types of soil.

The identification of microorganisms that use hydrocarbons as a $\mathrm{C}$ source and that present tolerance to contaminants has been reported in areas with a history of contamination by petroleum hydrocarbons and in many different types of soil (Richard \& Vogel, 1999; Van Beilen et al., 2002; Widada et al. 2002). The predominance of the Pseudomonas genus was expected, based on the number of published studies that describe the frequency of these in contaminated soils (Wunsche et al., 1995; Pirôllo, 2008; Higashioka et al. 2009), as well as their efficiency in the degradation of hydrocarbons (Whyte et al., 1997, Obuekwe et al., 2008, Bishnoi et al., 2009). The tolerance and the predominance of this genus of bacteria in environments contaminated by hydrocarbon compounds could be associated to specific catabolic pathways which involve different genes and enzymes which transform complex molecules contained in petroleum into common intermediate products from their catabolic routs. Furthermore, a large number of Pseudomonas species which are capable of using petroleum hydrocarbons as a $\mathrm{C}$ source have been studied and their characteristics described (Whyte et al., 1997; Yuste et al., 2000; Dinkla et al., 2001).

Genus Parvibaculum is known as being composed by many species which are good consumers of surfactants, using these as sources of $\mathrm{C}$ and energy (Schleheck et al., 2003). The production of this compound by other members of the consortium probably was beneficial for the permanence of this distinct group of microorganisms. Studies show that when associated in consortiums, microorganisms increase their potential for producing biosurfactants (Bento et al., 2005a). Furthermore, diesel and crude oil are considered to be excellent $\mathrm{C}$ sources for the production of biosurfactants by microorganisms (Ilori et al., 2005), with Pseudomonas species being excellent producers of biosurfactants (Rahman \& Gakpe, 2008). According to Schleheck et al. (2000), with the LAS surfactant (Alquilbenzeno Linear Sulfonado) available as the only source of $\mathrm{C}$ and energy, it was easily degraded and assimilated by the isolated Parvibaculum lavamentivorans DS-1.

The present study allowed the identification of organisms which, isolated or associated in consortium, could potentially be explored in biotechnological processes for bioremediation which involve the degradation of hydrocarbons. Although no new group of microorganisms was identified in the processes for decomposing hydrocarbon residue, it was possible to quantify, in sampling terms, the taxons which were represented in more significant numbers.

\section{CONCLUSIONS}

1. The consortium assessed demonstrated a predominance of organisms from phylum Proteobacteria, with the Alpha, Beta and Gamma classes as the most prominent.

2. The predominant clones in the library showed similarities to genus Pseudomonas, Parvibaculum and Sphingobium respectively.

3. Partial sequencing of gene $16 \mathrm{~S} r R N A$, together with the analysis done by the DOTUR software, was capable of estimating diversity of the bacterial communities in the assessed consortium.

\section{LITERATURE CITED}

AGÊNCIA NACIONAL DO PETRÓLEO - ANP. Disponível e m : < h t t p : / / w w w a n p.gov.br/p etro/ desenvolvimento_dados.asp> Acesso em 05 de fev. 2009.

ASTSCHUL, S.F.; MADDEN, T.L.; SCHAFFER, A.A.; ZHANG, J.; ZHANG, Z.; MILLER, W. \& LIPMAN, D.J. Gapped BLAST and PSI-BLAST: A new generation of protein database search programs. Nucleic Acids Res., 25:33893402, 1997.

ATLAS, M.R. Microbiol degradtionof petroleum hydrocarbons: $\mathrm{Na}$ environmental perspective. Microbiol. Rev., 45:180209, 1981.

BAMFORTH, S.M. \& SINGLETON, I. Bioremediation of polycyclic aromatic hydrocarbons: Current knowledge and future directions. J. Chem. Technol. Biotechnol., 80:723736, 2005. 
BISHNOI, K.; SAIN, U.; KUMAR, R.; SINGH, R. \& BISHNOI, N.R. Distribution and biodegradation of polycyclic aromatic hydrocarbons in contaminated sites of Hisar (India). Indian J. Exper. Biol., 3:210-217, 2009.

BENTO, F.M.; CAMARGO, F.A.O.; OKEKE, B.C. \& FRANKENBERGER JR, W.T. Diversity of biosurfactant producing microorganisms isolated from soils contaminated with diesel oil. Microbiol. Res., 160:249-255, 2005a.

BENTO, F.M.; CAMARGO, F.A.O.; OKEKE, B.C. \& FRANKENBERGER JR, W.T. Comparative bioremediation of soils contaminated with diesel oil by natural attenuation, biostimulation and bioaugmentation. Biores. Technol., 96:1049-1055, 2005b.

BUSHNELL, L. D., \& HAAS, H. F. Utilization of certain hydrocarbons by microorganisms. J. Bacteriol., 41:653673,1941

CANHOS, V.P. \& VAZOLLER, R.F. Diversidade no domínio bactéria. In: JOLY, C.A. \& BICUDO, C.E.M., orgs. Biodiversidade do Estado de São Paulo, Brasil: Síntese do conhecimento ao final do século XX. 1 Microorganismos \& Vírus. São Paulo, FAPESP, 1997. v.1. p.1-13.

CANTÃO, M.E.; FERREIRA, J.E. \& LEMOS, E.G.M. Optimal clone identifier for genomic shotgun libraries: OC Identifier tool. Genet. Molec. Res., 6:743-755, 2007.

COMPANHIA DE TECNOLOGIA DE SANEAMENTO AMBIENTAL - CETESB. Relação de áreas contaminadas. Disponível em: http://www.cetesb.sp.gov.br/Solo/ areas_contaminadas/texto_areas_cont_nov_09_pdf. Acesso em 05 de Fev., 2009.

COLE, J.R.; WANG, Q.; CARDENAS, E.; FISH, J.; CHAI, B.; FARRIS, R.J.; KULAM-SYED-MOHIDEEN, A.S.; MCGARRELL, D.M.; MARSH, T.; GARRITY, G.M. \& TIEDJE, J.M. The Ribosomal Database Project: Improved alignments and new tools for rRNA analysis. Nucl. Acids Res., 37:141-145, 2009.

DINKLA, I.J.T.; GABOR, E.M. \& JANSSEN, D.B. Effects of iron limitation on the degradation of toluene by Pseudomonas strains carrying the TOL (pWWO) plasmid. Appl. Environ. Microbiol. 67:3406-3412, 2001.

EWING, B. \& GREEN, P. Base-calling of automated sequencer traces using phred. II. Error probabilities. Genome Res., 8:186-194. 1998

EWING, B.; HILLIER, L.; WENDL, M.C. \& GREEN, P. Basecalling of automated sequencer traces using phred. I. Accuracy assessment. Genome Res., 8:175-185, 1998.

FALSENSTEN, J. PHYLIP-Phylogeny inference package (version 3.2). Cladistics, 5:164-166, 1989.

GALLEGO, J.R.; LOREDO, J.; LLAMAS, J.F.; VAZQUEZ, F. \& SANCHEZ, J. Bioremediation of diesel-contaminated soils: Evaluation of potential in situ techniques by study of bacterial degradation. Biodegradation, 12:325-335, 2001.

GARRITY, G.M.; BELL, J.A. \& LILBURN, T.G. Taxonomic outline of the Prokaryotes. Bergey's manual of systematic bacteriology. 2.ed. Relaease 5.0. New York, Springer, 2004.
HANAHAN, D. Studies on transformation of Escherichia coli with plasmids. J. Molec. Biol. 166:557-580, 1983

HIGASHIOKA, Y.; KOJIMA, H.; SATO, S. \& FUKUI, M. Microbial community analysis at crude oil-contaminated soils targeting the $16 \mathrm{~S}$ ribosomal RNA, xylM, C23O, and bcr genes. J. Appl. Microbiol., 105:1364-5072, 2009.

HURST, C.J.; CRAWFORD, R.L.; KNUDSEN, G.R.; MCINERNEY, M.J. \& STETZENBACH, L.D. Manual of environmental microbiology. 2.ed. Washington, ASM Press, 2002. 1138p.

ILORI, M.O.; AMOBI, C.J. \& ODOCHA, A.C. Factors affecting the production of oil degrading Aeromonas sp. Isolated from a typical environment. Chemosphere, 7:985-992, 2005 .

JACQUES, R.J.S.; BENTO, F.M.; ANTONIOLLI, Z.I. \& CAMARGO, F.A.O. Biorremediação de solos contaminados com hidrocarbonetos aromáticos policíclicos. Ci. Rural, 37:1192-1201, 2007.

KIMURA, M. A simple method for estimating evolutionary rates of base substitutions through comparative studies of nucleotide sequences. J. Molec. Evol., 16:111-120, 1980.

KOWALCHUK, G.A.; DE BRUIJN, F.J.; HEAD, I.M.; AKKERMANS, A.D. \& van ELSAS, J.D., eds. Molecular microbial ecology manual. 2.ed. Dordrecht, Kluwer, 2004. $2 \mathrm{v}$.

KUSKE, C.R.; BARNS, S.M. \& BUSCH, J.D. Diverse uncultivated bacterial groups from soils of the arid Southwestern United States that are present in many geographic regions. Appl. Environ. Microbiol., 63:36143621, 1997.

LUDWIG, W \& SCHLEIFER, K.H. Bacterial phylogeny based on $16 \mathrm{~S}$ and $23 \mathrm{~S}$ rRNA sequence analysis. FEMS Microbiol. Rev., 15:155-173, 1994.

MCCAIG, A.E.; GLOVER, A. \& PROSSER J.I. Molecular analysis of bacterial community struture and diversity in unimproved and improved upland grass pastures. Appl. Environ. Microbiol.; 4:1721-30, 1999.

NERCESSIAN, O.; FOUQUET, Y.; PIERRE, C.; PRIEUR, D. \& JEANTHON, C. Diversity of Bacteria and Archaea associated with a carbonate-rich metalliferous sediment sample from the Rainbow vent field on the Mid-Atlantic Ridge. Environ. Microbiol., 5:698-714, 2005.

OBUEKWE, C.O.; AL-JADI, Z.K. \& AL-SALEH, E.S. Comparative hydrocarbon utilization by hydrophobic and hydrophilic variants of Pseudomonas aeruginosa. J. Appl. Microbiol., 105:1876-1887, 2008.

OZAKI, S.; KISHIMOTO, N. \& FUJITA, T. Isolation and phylogenetic characterization of microbial consortia able to degrade aromatic hydrocarbons at high rates. Microbes Environ., 21:44-52, 2006.

PEREIRA, R.M.; SILVEIRA, E.L.; SCAQUITTO, D.C.; PEDRINHO, E.A.N.; VAL-MORAES, S.P.; WICKERT, E.; CARARETO-ALVES, L.M. \& LEMOS, E.G.M. Molecular characterization of bacterial populations of different soils. Braz. J. Microbiol., 37:439-447, 2006. 
PIRÔLLO, P.S.; MARIANO, A.P.; LOVAGLIO, R.B.; COSTA, S.G.V.A.O.; WALTER, V.; HAUSMANN, R. \& CONTIERO, J. Biosurfactant synthesis by Pseudomonas aeruginosa LBI isolated from a hydrocarbon-contaminated site. J. Appl. Microbiol., 105:1484-1490, 2008.

RAHMAN, P.K.S.M. \& GAKPE, E. Production, characterization and applications of Biosurfactants Review Biotechnology, 7:360-370, 2008.

RICHARD, J.Y. \& VOGEL, T.M. Characterization of a soil bacterial consortium capable of degrading diesel fuel. Inter. Biodeter. Biodegrad., 44:93-100, 1999.

ROESCH, L.F.W.; PASSAGLIA, L.M.P.; BENTO, F.M.; TRIPLETT, E.W. \& CAMARGO, F.A.O. Diversidade de bactérias diazotróficas endofíticas associadas a plantas de milho. R. Bras. Ci. Solo, 31:1367-1380, 2007.

SAITOU, N \& NEI, M. The neighbor-joining metod: A new method for constructing phylogenetic trees. Molec. Biol. Evol., 4:406-425, 1987.

SAMBROOK, J. \& RUSSELL, D.W. Molecular cloning: A laboratory manual. New York, Cold Spring Harbor Laboratory Press, 2001.

SCHLEHECK, D.; DONG, W.; DENGER, K.; HEINZLE, E. \& COOK, A.M. An á-proteobacterium converts linear alkylbenzenesulfonate surfactants into sulfophenyl carboxylates and linear alkyldiphenyletherdisulfonate surfactants into sulfodiphenylethercarboxylates. Appl. Environ. Microbiol., 66:1911-1916, 2000.

SCHLEHECK, D.; LECHNER, M.; SCHONENBERGER, R.; SUTER, M.J.F. \& COOK, A.M. Desulfonation and degradation of the disulfodiphenylethercarboxylates from linear alkyldiphenyletherdisulfonate surfactants. Appl. Environ. Microbiol., 69:938-944, 2003.

SCHLOSS, P.D. \& HANDELSMAN, J. Introducing DOTUR, a computer program for defining operational taxonomic units and estimating species richness. Appl. Environ. Microbiol., 71:1501-1506, 2005.

SILVEIRA, E.L.; PEREIRA, R.M.; SCAQUITTO, D.C.; PEDRINHO, E.A.N.; VAL-MORAES, S.P.; WICKERT, E.; CARARETO-ALVES, L.M. \& LEMOS, E.G.M. Bacterial diversity of soil under eucalyptus assessed by $16 \mathrm{~S}$ rDNA sequencing analysis. Pesq. Agropec. Bras., 41:1507-1516, 2006.

TAMURA, K.; DUDLEY, J.; NEI, M. \& KUMAR, S. MEGA4: Molecular Evolutionary Genetics Analysis (MEGA) software version 4.0. Molec. Biol. Evol., 24:1596-1599, 2007.
THOMPSON, J.D.; GIBSON, T.J.; PLEWNIAK, F.; JEANMOUGIN, F. \& HIGGINS, D.G. The CLUSTAL_X windows interface: Flexible strategies for multiple sequence alignment aided by quality analysis tools. Nucleic Acids Res., 25:4876-4882, 1997.

VAL-MORAES, S.P.; GHINI, R.; VALARINI, M.J.; LEMOS, E.G.M. \& CARARETO-ALVES, L.M. Diversidade de bactérias de solo sob vegetação natural e cultivo de hortaliças. R. Ci. Agron., 40:7-16, 2009.

TOLEDO, B.F.B.; MARCONDES, J. \& LEMOS, E.G.M. Caracterização de rizóbios indicados para produção de inoculantes por meio de sequenciamento parcial do 16S rRNA. Pesq. Agropec. Bras., 44:384-391, 2009.

van BEILEN, J.B.; SMITS, T.H.M.; WHYTE, L.G.; SCHORCHT, S.; RÖTHLISBERGER， M.; PLAGGEMEIER，T.; ENGESSER, K.H. \& WITHOLT, B. Alkane hydroxylase homologues in gram positive strains. Environ. Microbiol., 11:676-682, 2002

WANG, Q.; GARRITY, G.M.; TIEDJE, J.M. \& COLE, J.R. Naive Bayesian classifier for rapid assignment of rRNA sequences into the new bacterial taxonomy. Appl. Environ. Microbiol., 73:5261-5267, 2007.

WEISBURG, W.G.; BARNS, S.M.; PELLETIER, D.A. \& LANE, D.J. 16S ribossomal DNA amplification for phylogenetic study. J. Bacteriol., 173:697-703, 1991.

WHYTE, L.G.; BOURBONNIERE, L. \& GREER, C.W Biodegradation of petroleum hydrocarbons by psychrotrophic Pseudomonas strains possessing both alkane $(a l k)$ and naphthalene $(n a h)$ catabolic pathways. Appl. Environ. Microbiol., 63:3719-3723, 1997.

WIDADA, J.; NOJIRI, H.; KASUGA, K.; YOSHIDA, T.; HABE, H. \& OMORI, T. Molecular detection and diversity of polycyclic aromatic hydrocarbon-degrading bacteria isolated from geographically diverse sites. Appl. Microbiol. Biotechnol., 58:202-209, 2002.

WUNSCHE, L.; BRÜGGEMANN, L. \& BABEL, W. Determination of substrate utilization patterns of soil microbial communities: An approach to assess population changes after hydrocarbon pollution. FEMS Microbiol. Ecol., 17:295-305, 1995.

YUSTE, L.; CORBELLA, M.E.; TURIGANO, M.J.; KARLSON, U.; PUYET, A. \& ROJOA, F. Characterization of bacterial strains able to grow on high molecular mass residues from crude oil processing. FEMS Microbiol. Ecol., 32:69$75,2000$. 